\title{
Phytochemical Contents of Five Artemisia Species
}

\author{
Murat KURSAT ${ }^{1 *}$, Irfan EMRE², Okkeş YILMAZ³, Semsettin CIVELEK ${ }^{3}$, \\ Ersin DEMIR ${ }^{4}$, Ismail TURKOGLU ${ }^{5}$
}

\author{
IBitlisEren University, Faculty of Sciences and Arts, Department of Biology, Bitlis, 13000, Turkey; botanikkursat@hotmail.com (*correspondingauthor) \\ ${ }^{2}$ Firat University, Faculty of Education, Department of Primary Education, 23119 Elazig, Turkey \\ ${ }^{3}$ Firat University, Faculty of Sciences and Arts, Department of Biology, 23119 Elazig, Turkey \\ ${ }^{4}$ Duzce University, Faculty of Agriculture and Natural Sciences, Duzce, Turkey \\ ${ }^{5}$ Firat University, Faculty of Education, Department of Secondary Science and Mathematics Education, 23119 Elazig, Turkey
}

\begin{abstract}
In the present study, the fatty acid compositions, vitamin, sterol contents and flavonoid constituents of five Turkish Artemisia species (A. armeniaca, A. incana, A. tournefortiana, A. haussknechtii and A. scoparia) were determined by GC and HPLC techniques. The results of the fatty acid analysis showed that Artemisia species possess high saturated fatty acid compositions. On the other hand, the studied Artemisia species were found to have low vitamin and sterol contents. Eight flavononids (catechin, naringin, rutin, myricetin, morin, naringenin, quercetin, kaempferol) were determined in the present study. It was found that Artemisia species contained high levels of flavonoids. Morin $(45.35 \pm 0.65-1406.79 \pm 4.12 \mu \mathrm{g} / \mathrm{g})$ and naringenin $(15.32 \pm 0.46-191.18 \pm 1.22 \mu \mathrm{g} / \mathrm{g})$ were identified in all five species. Naringin $(268.13 \pm 1.52-226.43 \pm 1.17 \mu \mathrm{g} / \mathrm{g})$ and kaempferol $(21.74 \pm 0.65-262.19 \pm 1.38 \mu \mathrm{g} / \mathrm{g})$ contents were noted in the present study. Present research showed that the studied Artemisia taxa have high saturated fatty acids and also rich flavonoid content.
\end{abstract}

Keywords: Artemisia, fatty acid, flavonoid, sterol, vitamin

\section{Introduction}

Artemisia L. is the largest genus in the tribe Anthemideae of the Asteraceae, which comprises 400-500 species (Martin et al., 2001; Kreitschiz and Valles, 2007). Most of these species grow wild in dry or semi-dry habitats throughout the Northern regions of the world (Torrell and Valles, 2001; Valles et al., 2003; Singh et al., 2009). The genus is composed of perennial, biennial and annual herbs or small shrubs, which are frequently aromatic (Kordali et al., 2005; Kursat, 2010). There are 23 Artemisia species in the flora of Turkey, which are distributed throughout the country (Davis, 1975).

In the traditional herbal medicine, aerial parts of Artemisia are being used for its antimalarial, antimicrobial, antioxidant, antifungal, anticholesterolemic, antidiabetic, antihelminth, antiseptic, antitumor, antipyretic and antispasmodic effects (Chopra et al., 1992; Koul, 1997; Cimbiz et al., 2005; Han et al., 2007; Temraz and El-Tantawy, 2008; Sengul et al., 2011; Afshar et al., 2013). Several studies showed that polyphenols, flavonoids, cinnamic acid derivatives and coumarines were found in Artemisia species (Esteban et al, 1986; Rauter et al., 1989; Mojarrab et al., 2011; Afsar et al., 2012; Suresh et al, 2012). Plant phenolics are widespread natural compounds and are probably responsible for the antioxidant activity by thier hydroxyl groups, and thus have the ability to neutralize free radicals (Fukumato and Mazza, 2000; Ruikar et al., 2011; Bandli and Heidari, 2014).
Natural and cultivated Turkish herbs are being more widely used on a commercial scale in the food industry and in traditional medicine (Baytop, 1999; Erdemoglu et al., 2007). To support the use of herbal medicine and to detect their potential as possible drugs it is necessary to work medicinal plants (Sengul et al., 2011). The aim of the present study was to establish possible medicinal properties of some Artemisia species by determining the fatty acid compositions, vitamin and sterol contents, flavonoid constituents of aerial parts, of five Artemisia species growing in Turkey.

\section{Materials and Methods}

\section{Chemicals}

All chemicals, solvents and standards were purchased from Sigma-Aldrich-Fluka (Taufkirchen, Germany) or Merck (Darmstadt, Germany).

\section{Plant materials}

The present study examined plant extracts of five Artemisia species: $A$. armeniaca Lam. $A$. incana (L.) Druce, $A$. tournefortiana Reichb., A. haussknechtii Boiss. and A. scoparia Waldst. \& Kit. Sample plants were collected from their natural habitats. Details about the plant materials are shown in Table 1. Voucher specimens of studied plants were deposited at the Herbarium of Firat University (FUH). All experiments were performed in triplicate. 
496

\section{Extraction of plant oils}

Two g aerial parts of plant material were finely grounded in a mill and were then extracted with n-hexane/isopropanol $(3: 2$ $\mathrm{v} / \mathrm{v}$ ) (Hara and Radin, 1978). The lipid extracts were centrifuged at 10,000 rpm for $5 \mathrm{~min}$ and filtered; the solvent was then removed on a rotary evaporator at $40{ }^{\circ} \mathrm{C}$. The extracted lipids were stored under $-25^{\circ} \mathrm{C}$ until further analysis.

\section{Fatty acid analyses}

Fatty acid in the lipid extracts were converted into methyl esters by means of $2 \%$ sulphuric acid (v/v) in methanol (Christie, 1990). The fatty acid methyl esters were extracted with $n$-hexane. The methyl esters were then separated and quantified by gas chromatography and flame-ionization detection (Shimadzu GC 17 Ver.3) coupled to a CLASS GC 10 software computer software. Chromatography was performed with a capillary column $(0.25 \mathrm{~mm}$ in diameter, Permabound 25, Macherey-Nagel, Germany) using nitrogen as a carrier gas (flow rate $0.8 \mathrm{ml} / \mathrm{min}$.). The temperatures of the column, detector and injection valve were 130-220, 240 and $280{ }^{\circ} \mathrm{C}$, respectively. Identification of the individual methyl esters was performed by frequent comparison with authentic standard mixtures that were analysed under the same conditions. Retention time for studied Artemisia species was determined as $3.34 \mathrm{~min}$ - A. armeniaca, $3.81 \mathrm{~min}-A$. incana, $9.47 \mathrm{~min}$ - A. tournefortiana, $17.40 \mathrm{~min}-$ A. haussknechtii, 1.41 min - A. scoparia.

Chromatographic analysis and quantification of lipid soluble vitamins and sterols

Lipide-soluble vitamins and phytosterols were extracted from the lipid fraction by the method of Sánchez-Machado (Sánchez-Machado et al., 2002) with minor modifications. The extracted lipids of plant material were dissolved in acetonitrile/methanol $(75 / 25 \mathrm{v} / \mathrm{v})$ and were injected $50 \mu \mathrm{L}$ to HPLC UV detector (SPD-10AVP) instrument (Shimadzu, Kyota Japan). A Supelcosil LC18 ( 250 x 4.6 mm, 5 m, Sigma, USA) column was used. The mobile phase was acetonitrile/methanol $(75 / 25, \mathrm{v} / \mathrm{v})$ and the elution was performed at a flow-rate of $1 \mathrm{ml} / \mathrm{min}$ The temperature of analytical column was kept at $40^{\circ} \mathrm{C}$. Detection was performed at $320 \mathrm{~nm}$ for retinol (vitamin A) and retinol acetate, and $215 \mathrm{~nm}$ for $\delta$-tocopherol, vitamin D, $\alpha$-tocopherol, $\alpha$-tocopherol acetate, $202 \mathrm{~nm}$ for phytosterols, $265 \mathrm{~nm}$ for vitamin K1. Identification of the individual vitamins and phytosterols was performed by frequent comparison with authentic external standard mixtures (K2: $1.8 \mu \mathrm{g} / 5 \mathrm{ml}$; K1: $1.89 \mu \mathrm{g} / 5 \mathrm{ml}$; R-tocopherol: $1.84 \mu \mathrm{g} / 5 \mathrm{ml}$; D2: $2.14 \mu \mathrm{g} / 5 \mathrm{ml}$; D3: $2.25 \mu \mathrm{g} / 5 \mathrm{ml}$; $\alpha$-tocopherol: $3.61 \mu \mathrm{g} / 5 \mathrm{ml}$; retinol: $1.4 \mathrm{\mu g} / 5 \mathrm{ml}$; retinol acetate: $3.14 \mu \mathrm{g} / 5 \mathrm{ml}$; ergosterol: 9.78 $\mu \mathrm{g} / 5 \mathrm{ml}$; stigmasterol: $5.73 \mu \mathrm{g} / 5 \mathrm{ml} ; \beta$-sitosterol: $3.1 \mu \mathrm{g} / 5 \mathrm{ml}$ ) analysed under the same conditions (López-Cervantes et al,, 2006). Retention time for studied Artemisia species was determined as 6.79 $\min (\mathrm{K} 2), 14.65 \mathrm{~min}$ (K1), $7.94 \mathrm{~min}$ (R-tocopherol), $8.82 \mathrm{~min}$ (D2), $9.46 \mathrm{~min}$ (D3), $10.23 \mathrm{~min}$ ( $\alpha$-tocopherol), $3.65 \mathrm{~min}$ (retinol), $3.95 \mathrm{~min}$ (retinol acetate), $11.57 \mathrm{~min}$ (ergosterol), $18.35 \mathrm{~min}$ (stigmasterol), $20.67 \mathrm{~min}$ ( $\beta$-sitosterol).

\section{Statistical analysis}

Class Vp 6.1 software assisted at workup of the data. The results of analysis were expressed as $\mu \mathrm{g} / \mathrm{g}$ for samples. Vitamine, sterol and flavonoid contents are given mean \pm standard deviation as $\mu \mathrm{g} / \mathrm{g}$. Fatty acid compositions are given mean \pm standart deviation (\%).

\section{Flavonoid analysis}

Preparation of the extracts

Two g aerial parts of Artemisia were homogenized in $5 \mathrm{ml}$ $80 \%$ methanol. Homogenates were centrifuged at $5,000 \mathrm{rpm}$ at $+4{ }^{\circ} \mathrm{C}$. After centrifugation, the supernatant was concentrated by reduced-pressure rotary evaporation. Extract was resuspended in $1 \mathrm{ml}$ dimethyl sulphoxide (DMSO) to produce a stock solution.

\section{Chromatographic conditions for flavonoids}

Chromatographic analysis was carried out using a PREVAIL C18 reversed-phase column ( 15 x $4.6 \mathrm{~mm}, 5 \mu \mathrm{m}$, USA); the mobile phase was methanol/water/acetonitrile (46/46/8, v/v/v) containing $1.0 \%$ acetic acid ( $\mathrm{Zu}$ et al., 2006). The mobile phase was filtered through a $0.45 \mu \mathrm{m}$ membrane filter (Millipore). Catechin (CA), naringin (NA), rutin (RU), myricetin (MYR), morin (MOR), naringenin (NAR), quercetin (QU) and kaempferol (KA) were quantified by DAD separation at $280 \mathrm{~nm}$ for CA and NA, $254 \mathrm{~nm}$ for RU, MYR, MOR and QU, and $265 \mathrm{~nm}$ for KA. Flow rate and injection volume were 1.0 $\mathrm{ml} / \mathrm{min}$ and $10 \mu \mathrm{L}$, respectively. The chromatographic peaks of the extracts were confirmed by comparing their retention time with that of the reference standards. Quantification was carried out by the integration of the peak using the external standard method. All chromatographic operations were carried out at a temperature of $25^{\circ} \mathrm{C}$.

\section{Results and Discussion}

Fatty acid compositions, vitamin and sterol contents of Artemisia species

The fatty acid compositions of the studied Artemisia species were summarized in Table 2 . The dominant fatty acids in the Artemisia species were found to be palmitic acid, stearic acid, palmitoleic acid, oleic acid, linoleic acid, eicosadienoic acid and docosadienoic acid. A. armeniaca, A. haussknechtii and $A$. scoparia contained the highest saturated fatty acid contents, at $65.21 \pm 0.51 \%, 39.84 \pm 0.49 \%$ and $58.01 \pm 0.36 \%$, respectively. Analysis by Orhan $e t$ al. (2009) of the fatty acid contents of different genus of Asteraceae suggested that most of the extracts seemed to be rich in saturated fatty acids.

Palmitoleic acid and oleic acid were found as monounsaturated fatty acids in all Artemisia species studied. $A$. tournefortiana and $A$. haussknechtii contained high levels of monounsaturated fatty acid $(15.56 \pm 0.28 \%$ and $20.58 \pm 0.36 \%$, respectively). Linoleic acid, eicosadienoic acid and docosadienoic acid were dominant polyunsaturated fatty acids in the five Artemisia species studied. Linolenic acid was absent or present at low levels in the studied species, except for $A$. incana, in which the linolenic acid content was found to be $22.21 \pm 0.43 \%$. Similarly, Orhan et al. (2009) found that the linoleic acid constituent of different species of Asteraceae was low or absent. Carvalho et al. (2011a) determined palmitic acid is major saturated fatty acid and linoleic acid and linolenic acids are major unsaturated fatty acids in the studied thirteen Artemisia species

The sterol and vitamin contents of the five Artemisia species studied are shown in Table 3. A. armeniaca had high ergosterol $(164.75 \pm 2.34 \mu \mathrm{g} / \mathrm{g})$ and $\beta$-sitosterol $(26.5 \pm 1.23 \mu \mathrm{g} / \mathrm{g})$ contents, but low stigmasterol content. The presence of sitosterol and ergosterol in $A$. annua was reported by Abid Ali Khan $e t$ al. (1991). Several previous studies indicated that phytosterols, such 
as $\beta$-sitosterol, were most effective against reactive oxygen species (Vivacons and Moreno, 2005; Conforti et al., 2009). Furthermore, the present study showed that the Artemisia species studied had low vitamin contents. Brisibe et al. (2009) reported that the vitamin A content of $A$. annua was below 0.3 $\mathrm{g} / 100 \mathrm{~g}$, while vitamin $\mathrm{E}$ was determined to be at high levels in $A$. annua leaves $(22.63 \mathrm{mg} / \mathrm{kg})$.

\section{Flavonoid contents of Artemisia species}

It was reported that phenolic compounds possess potent antioxidant activity and have anticancer or anticarcinogenic/anti-mutagenic, antibacterial, antiviral or antiinflammatory properties (Bo et al., 2002; Cai et al., 2006). The flavonoid content of Artemisia species are shown in Table 4. Artemisia species are generally known as rich sources of antioxidant such as flavonoids and coumarins (Toda, 2005; Brisibe et al., 2009). The present study found that $A$. armeniaca had the highest flavonoid composition, while $A$. haussknechtii had less variety of flavonoid than other species studied. Mino $e t$ al. (2004) reported that Artemisia species included luteolin and kaempferol constituents. Also, Djeridane et al. (2006) concluded that all the plant species they studied including Artemisia species such as Artemisia campestris, Artemisia herba-alba and Artemisia arborescens- were rich in flavonoids. Furthermore, previous studies showed that different Artemisia species contain apigenin, luteolin, rutin, kaempferol, quercetin and naringenin constituents (Valant-Vetschera et al., 2003; Cai et al., 2004; Carvalho et al., 2011b; Suresh et al., 2012). Suresh et al. (2012) suggested that Artemisia species have significant amount of polyphenols and flavonoids content. Therefore these species could be considered in the category of antioxidant, anticancer, antimicrobial and immunomodulatory. Also, Carvalho et al. (2011b) found total phenolic content between 0.22-0.39 mg/gGAE in the leaves of Artemisia species. Also they determined the kaempherol the major flavonoid in the six Artemisia leaves, which measured in higher amounts 47.56 $\mu \mathrm{g} / \mathrm{g}$. However, quercetin and myricetin were determined in much lower quantities in the six Artemisia species (Carvalho et al., 2011b). Sengul et al. (2011) found that total phenolic content of Artemisia species were between $9.79 \mu \mathrm{g} \mathrm{GAE} / \mathrm{mg}$ and $15.38 \mu \mathrm{g} \mathrm{GAE} / \mathrm{mg}$. On the other hand, Lee et al. (2013) determined that myricetin amount was $1,086.55 \mathrm{mg} / 100 \mathrm{~g}$,

Table 1. Grown site of investigated Artemisia species

\begin{tabular}{|c|c|c|}
\hline Species & Grown sites & Herbarium no. \\
\hline A. armeniaca Lam. & Agri, Dogubeyazit, Bardakli village, 2565 m, N 39 43.601, E 44º 03.501, 23.09.2007 & 1068 \\
\hline A. incana (L.) Druce & Bitlis, Adilcevaz, 1720 m, N $38^{\circ} 47.855$, E $42^{\circ}$ 43.000, 23.09.2007 & 1075 \\
\hline A. tournefortiana Reichb. & Van, Gurpinar, Hamurkesen village, 1953 m, N 38²0.774, E 43 37.377, 20.09.2007 & 1055 \\
\hline A. haussknechtii Boiss. & Hakkari, Kırıkdag village, 1624 m, N 37º 34.873 , E 43 54.148, 21.09.2007 & 1059 \\
\hline A. scoparia Waldst \& Kit. & Ankara, Polatli road, 20 th km, $796 \mathrm{~m}, \mathrm{~N} 39^{\circ} 42.876$, E $32^{\circ} 17.941,10.09 .2007$ & 1030 \\
\hline
\end{tabular}

Table 2. Fatty acid compositions (\%) of investigated Artemisia species

SFA: Saturated fatty acids MUFA: Monounsaturated fatty acids PUFA: Polyunsaturated fatty acids USFA: Unsaturated fatty acids

\begin{tabular}{|c|c|c|c|c|c|}
\hline Fatty acids (\%) & A. armeniaca & A. incana & A. tournefortiana & A. haussknechtii & A. scoparia \\
\hline Myristic acid & - & - & - & - & $10.71 \pm 0.32$ \\
\hline Palmitic acid & $24.46 \pm 0.68$ & $9.76 \pm 0.26$ & $11.32 \pm 0.41$ & $16.67 \pm 0.39$ & $20.39 \pm 0.24$ \\
\hline Margaric acid & - & $4.37 \pm 0.54$ & - & - & - \\
\hline Stearic acid & $23.47 \pm 0.44$ & $3.04 \pm 0.27$ & $3.18 \pm 0.32$ & $4.77 \pm 0.39$ & $11.76 \pm 0.43$ \\
\hline Arachidic acid & $4.37 \pm 0,41$ & - & $1.36 \pm 0.32$ & - & $4.38 \pm 0.51$ \\
\hline Behenic acid & $4.02 \pm 0.46$ & - & $1.04 \pm 0.19$ & $10.47 \pm 0.21$ & $3.01 \pm 0.23$ \\
\hline Tricosylic acid & $5.52 \pm 0.76$ & - & $3.82 \pm 0.23$ & $3.82 \pm 0.62$ & - \\
\hline Lignoceric acid & $3.37 \pm 0.33$ & - & $1.62 \pm 0.36$ & $4.11 \pm 0.89$ & $7.76 \pm 0.45$ \\
\hline$\Sigma$ SFA & $65.21 \pm 0.51$ & $17.17 \pm 0.35$ & $22.34 \pm 0.3$ & $39.84 \pm 0.49$ & $58.01 \pm 0.36$ \\
\hline Palmitoleic acid & $3.37 \pm 0.33$ & $3.08 \pm 0.55$ & $6.46 \pm 0.32$ & $8.61 \pm 0.32$ & $4.53 \pm 0.27$ \\
\hline Oleic acid & $6.13 \pm 0.29$ & $2.59 \pm 0.34$ & $9.1 \pm 0.25$ & $11.97 \pm 0.41$ & $6.23 \pm 0.29$ \\
\hline$\Sigma$ MUFA & $9.5 \pm 0.31$ & $5.67 \pm 0.44$ & $15.56 \pm 0.28$ & $20.58 \pm 0.36$ & $10.76 \pm 0.28$ \\
\hline Linoleic acid & $9.94 \pm 0.28$ & $12.98 \pm 0.33$ & $37.23 \pm 0.47$ & $15.84 \pm 0.51$ & $14.42 \pm 0.23$ \\
\hline Eicosadienoic acid & $4.77 \pm 0.38$ & $23.41 \pm 0.32$ & $12.24 \pm 0.28$ & $6.68 \pm 0.33$ & $1.81 \pm 0.27$ \\
\hline Arachidonic acid & $6.47 \pm 0.22$ & $7.79 \pm 0.45$ & $2.61 \pm 0.39$ & $7.44 \pm 0.37$ & $3.17 \pm 0.36$ \\
\hline$\alpha$-linolenic acid & $4.42 \pm 0.33$ & $22.21 \pm 0.43$ & $1.34 \pm 0.32$ & - & - \\
\hline$\gamma$-linolenic acid & - & $2.25 \pm 0.42$ & $3.83 \pm 0.39$ & - & $2.07 \pm 0.23$ \\
\hline Stearidonic acid & - & $9.11 \pm 0.52$ & $5.86 \pm 0.49$ & $9.72 \pm 0.27$ & $9.83 \pm 0.41$ \\
\hline ¿PUFA & $25.6 \pm 0.3$ & $77.75 \pm 0.41$ & $63.11 \pm 0.39$ & $39.68 \pm 0.37$ & $31.13 \pm 0.3$ \\
\hline$\Sigma$ USFA & $35.1 \pm 0.3$ & $83.42 \pm 0.42$ & $78.67 \pm 0.33$ & $60.1 \pm 0.32$ & $42.06 \pm 0.29$ \\
\hline
\end{tabular}

Table 3. Vitamin and sterol contents of investigated Artemisia species

\begin{tabular}{lccccccccccc}
\hline \multicolumn{1}{c}{ Species } & $\mathrm{K} 2$ & $\mathrm{~K} 1$ & $\begin{array}{c}\mathrm{R}- \\
\text { tocopherol }\end{array}$ & $\mathrm{D} 2$ & $\mathrm{D} 3$ & $\begin{array}{c}\alpha- \\
\text { tocopherol }\end{array}$ & Retinol & $\begin{array}{c}\text { Retinol } \\
\text { acetate }\end{array}$ & Ergosterol & Stigmasterol & $\beta$ Bitosterol \\
\hline A. armeniaca & $0.67 \pm 0.12$ & $2.72 \pm 0.28$ & $0.16 \pm 0.09$ & $0.32 \pm 0.11$ & - & $23.12 \pm 1.21$ & $0.14 \pm 0.02$ & $0.13 \pm 0.06$ & $164.75 \pm 2.34$ & $1.81 \pm 0.13$ & $26.5 \pm 1.23$ \\
A. incana & $0.32 \pm 0.09$ & $1.11 \pm 0.15$ & $0.32 \pm 0.14$ & $1.97 \pm 0.44$ & $0.32 \pm 0.13$ & $0.11 \pm 0.02$ & - & - & $11.22 \pm 1.43$ & $5.72 \pm 0.28$ & $1.93 \pm 0.17$ \\
A. toumefortiana & $1.21 \pm 0.16$ & $2.68 \pm 0.23$ & $2.51 \pm 0.16$ & $5.17 \pm 0.38$ & $0.87 \pm 0.23$ & - & - & - & $3.07 \pm 0.76$ & $16.76 \pm 1.57$ & $7.53 \pm 0.67$ \\
A. hausknechtii & $0.71 \pm 0.17$ & $1.1 \pm 0.15$ & $0.94 \pm 0.14$ & $2.34 \pm 0.25$ & - & - & - & - & $67.43 \pm 1.48$ & $0.74 \pm 0.11$ & $7.21 \pm 0.45$ \\
A. scoparia & - & $1.43 \pm 0.22$ & - & $0.32 \pm 0.18$ & $0.56 \pm 0.18$ & - & - & $1.71 \pm 0.15$ & - & $2.11 \pm 0.24$ & $0.62 \pm 0.13$ \\
\hline
\end{tabular}


498

Table 4. Flavonoid contents of studied Artemisia species

\begin{tabular}{ccccccc}
\hline Flavonoids $(\mu \mathrm{g} / \mathrm{g})$ & A. armeniaca & A. incana & A. tournefortiana & A.haussknechtii & A. scoparia & Retention time $(\mathrm{minute})$ \\
\hline Catechin & $11486.71 \pm 3.52$ & - & $2684.87 \pm 3.42$ & - & - & - \\
Naringin & $268.13 \pm 1.52$ & $226.43 \pm 1.17$ & - & - & 2.63 \\
Rutin & $6043.64 \pm 3.71$ & $7259.43 \pm 3.49$ & - & $5156.13 \pm 4.15$ & $11416.11 \pm 3.43$ \\
Myricetin & $17332.1 \pm 3.55$ & - & $76.25 \pm 1.11$ & $1861.44 \pm 1.77$ & $111.79 \pm 2.34$ & 3.12 \\
Morin & $1406.79 \pm 4.12$ & $457.74 \pm 1.57$ & $91.21 \pm 0.34$ & $45.35 \pm 0.65$ & $256.78 \pm 1.21$ & $97.76 \pm 1.11$ \\
Naringenin & $191.18 \pm 1.22$ & $15.32 \pm 0.46$ & $190.79 \pm 1.57$ & $42.18 \pm 0.75$ & $645.12 \pm 2.13$ \\
Quercetin & $223.32 \pm 2.01$ & $13.23 \pm 0.58$ & $101.69 \pm 2.13$ & - & 5.09 \\
Kaempferol & $36.56 \pm 0.35$ & - & $21.74 \pm 0.65$ & - & $262.19 \pm 1.38$ \\
\hline
\end{tabular}

quercetin amount was $30.90 \mathrm{mg} / 100 \mathrm{~g}$ and kaempherol amount was $12.95 \mathrm{~g} / 100 \mathrm{mg}$ in the Artemisia studied. In addition, they measured rutin as $44.00 \mathrm{mg} / 100 \mathrm{~g}$, resveratrol as $21.40 \mathrm{mg} / 100 \mathrm{~g}$ (Lee et al., 2013). Nouria and Omar (2014) indicated that phenolic compounds, tannins and flavonoids were the major constituents of Artemisia. In contrast to these findings, some previous studies indicated that some Artemisia species had low or no flavonoid content (Wojdylo et al., 2007; Li et al., 2008).

\section{Conclusions}

The results of the present study showed that Artemisia species contained high saturated fatty acid compositions and linoleic acid, the major polyunsaturated fatty acid. Moreover, it was found that studied Artemisia species were rich in flavonoid constituents. Morin and naringenin were determined within all five species analysed. However, it was found that the sterol and vitamin contents of Artemisia species under the present study were low.

\section{Acknowledgements}

This study was supported by The Scientific and Technological Research Council of Turkey (TUBITAK) with project number 106 T559.

\section{References}

Abid Ali Khan MM, Jain DC, Bhakuni RS, Zaim Mohd Thakur RS (1991). Occurrence of some antiviral sterols in Artemisia annua. Plant Science 75:161-5.

Afshar FH, Delazar A, Nazemiyeh H, Esnaashari S, Moghadam SB (2012). Comparision of the total phenol, flavonoid contents and antioxidant activity of methanolic extracts of Artemisia spicigera and $A$. splendens growing in Iran. Pharmaceutical Sciences 18(3):165-170.

Bandli K, Heidari R (2014). The evaluation of antioxidant activities and phenolic compounds in leaves and inflorescence of Artemisia dracunculus L. by HPLC. Journal of Medicinal Plants 13(51):4150.

Baytop T (1999). Therapy with medicinal plants in Turkey; today and in future. Istanbul, Istanbul University Press pp 166-167.

Bo QM, Wu ZY, Shun QS, Bao XS, Mao ZS, et al. (2002). Selection of the illustrated Chinese anti-cancer herbal medicines. Shanghai Science and Technology Literature Press, Shanghai, China.

Brisibe EA, Umeron EU, Brisibe F, Magalhäes PM, Ferreira JFS, Luthria D, Wu X, Prior RL (2009). Nutritional characterisation and antioxidant capacity of different tissues of Artemisia annua L. Food Chemistry 115:1240-1246.
Cai Y, Luo Q, Sun M, Corke H (2004). Antioxidant activity and phenolic compounds of 112 traditional Chinese medicinal plants associated with anticancer. Life Science 74(17):2157-2184.

Cai YZ, Mei Sun, Jie Xing, Luo Q, Corke H (2006). Structure-radical scavenging activity relationships of phenolic compounds from traditional Chinese medicinal plants. Life Science 78:2872-2888.

Carvalho IS, Teixeira MC, Brodelius M (2011a). Fatty acids profile of selected Artemisia spp. plants: Health promotion. LWT - Food Science and Technology 44:293-298

Carvalho IS, Cavaco T, Brodelius M (2011b). Phenolic composition and antioxidant capacity of six Artemisia species. Industrial Crops and Products 3:382-388.

Chopra RN, Nayer SL, Chopra IC (1992). Glossary of Indian Medicinal Plants, 3rd Ed. Council of Scientific and Industrial Research, New Delhi.

Christie WW (1990). Gas chromatography and lipids. The oily press: Glaskow UK pp 573-577.

Cimbiz A, Ozyurt MS, Dayioglu H, Helvaci MR, Yilmaz H (2005). Effect of herb extracts on stress, hyperglicemia, hyperlipidemia and hypercholesterolemia levels. Dumlupinar University Journal of Institute of Natural Sciences 9:1-14.

Conforti F, Sosa S, Marrelli M, Menichini F, Statti GA, Uzunov D, Tubaro A, Menichini F (2009). The protective ability of Mediterranean dietary plants against the oxidative damage: the role of radical oxygen species in inflammation and the polyphenol flavonoid and sterol contents. Food Chemistry 112:587-594.

Davis PH (1975). Artemisia L. In: Davis PH (Ed). Flora of Turkey and the East Aegean Islands, Vol. 5. Edinburgh University Press, Edinburgh pp 311-324.

Djeridane A, Yousfi M, Nadjemi B, Boutassouna D, Stocker P, Vidal $\mathrm{N}$ (2006). Antioxidant activity of some Algerian medicinal plants extracts containing phenolic compounds. Food Chemistry 97:654-660.

Fukumoto LR, Mazza G (2000). Assessing antioxidant and proxidant activities of phenolic compounds. Journal of Agricultural Food Chemistry 48(8):3597-604.

Erdemoglu N, Orhan İI, Kartal M, Adiguzel N, Bani B (2007). Determination of artemisinin in selected Artemisia L. species of Turkey by reversed phase HPLC. Records of Natural Products 1(2-3):36-43.

Esteban MD, Gonzalez Collado I, Macias FA, Massanet GM, Rodriguez Luis F (1986). Flavonoids from Artemisia lanata. Phytochemistry 25(6):1502-1504.

Han X, Shen T, Lou H (2007). Dietary polyphenols and their biological significance. International Journal of Molecular Science 8:950-988. 
Hara A, Radin NS (1978). Lipid extraction of tissues with a lowtoxicity solvent. Analytical Biochemistry 90(1):420-426.

Kordali S, Kotan R, Mavi A, Cakir A, Ala A, Yildirim A (2005). Determination of the chemical composition and antioxidant activity of the essential oil of Artemisia dracunculus and of the antifungal and antibacterial activities of Turkish Artemisia $A$. absinthium, A. dracunculus, Artemisia santonicum, and Artemisia spicigera essential oils. Journal of Agricultural Food Chemistry 53:9452-9458.

Koul MK (1997). Medicinal plants of Kashmir and Ladakh, temperate and cold arid Himalaya. Indus Publishing Company, FS-5, Tagore Garden, New Delhi.

Kreitschiz A, Valles J (2007). Achene morphology and slime structure in some taxa of Artemisia L. and Neopallasia L. (Asteraceae). Flora 202:570-580.

Kursat M (2010). Artemisia L. cinsinin taksonomik revizyonu. PhD, Fırat Üniversitesi Fen Bilimleri Enstitüsü, Elazig.

Li HB, Wong CC, Cheng KW, Chen F (2008). Antioxidant properties in vitro and total phenolic contents in methanol extracts from medicinal plants. LWT-Food Science and Technology 41:385-390.

Lee YJ, Thiruvengadam M, Chung, IM, Nagella P (2013). Polyphenol composition and antioxidant activity from the vegetable plant Artemisia absinthium L. Australian Journal of Crop Sciences 7(12):1921-1926.

López-Cervantes J, Sánchez-Machado DI, Ríos-Vázquez NJ (2006). High-performance liquid chromatography method for the simultaneous quantification of retinol, $\alpha$-tocopherol, and cholesterol in shrimp waste hydrolysate. Journal of Chromatography A 1105:135-139.

Mojarrab M, Delazar A, Moghadam SB, Nazemiyeh H, Nahar L, Kumarasamy Y, et al. (2011). Armenin and Isoarmenin - two prenylated coumarins from the aerial parts of Artemisia armeniaca. Chemistry and Biodiversity 8(11):2097-2103.

Martin J, Torrell M, Valles J (2001). Palynological features as a systematic marker in Artemisia L. and related genera (Asteraceae, Anthemideae). Plant Biology 3:372-378.

Miño J, Moscatelli V, Hnatyszyn O, Gorzalczany S, Acevedo C, Ferraro G (2004). Antinociceptive and antiinflammatory activities of Artemisia copa extracts. Pharmacological Resources 50:59-63.

Nouria H, Omar K (2014). Antioxidant activity and total phenolic content within the aerial parts of Artemisia absinthium. International Journal of Pharmacological and Pharmaceutical Sciences 1:11.

Orhan I, Orhan-Deliorman D, Ozçelik B (2009). Antiviral activity and cytotoxicity of lipophilic extracts of various edible plants and their fatty acids. Food Chemistry 115:701-705.

Rauter AP, Branco I, Tastao Z, Pais MS, Gonzalez AG, Bermejo JB. (1989). Flavonoids from Artemisia campestris subsp. maritima. Phytochemistry 28(8):2173-2175.
Ruikar AD, Ghayal NA, Misar AV, Mujumdar AM, Puranik VG, Deshpande NR (2011). Studies on aerial parts of Artemisia pallens Wall for phenol, flavonoid and evaluation antioxidant activity. Journal of Pharmacy Bioallied Science 3:302-305.

Sánchez-Machado DI, Lopez-Hernandez J, Paseiro-Losado P (2002). High-performance liquid chromatographic determination of $\alpha$ tocopherol in macroalgae. Journal of Chromatography A 976(1):277-284.

Sengul M, Ercisli S, Yildiz H, Gungor N, Kavaz A, Cetin B (2011). Antioxidant, antimicrobial activity and total phenolic content within the aerial parts of Artemisia absinthum, Artemisia santonicum and Saponaria officinalis. Iranian Journal of Pharmaceutical Research 10(1):49-56.

Singh HP, Mittal S, Kaur S, Batish DR, Kohli RK (2009). Chemical composition and antioxidant activity of essential oil from residues of Artemisia scoparia. Food Chemistry 114:642-645.

Suresh J, Ahuja J, Paramakrishnan N, Sebastian M (2012). Total phenolic and total flavonoids content of aerial parts of Artemisia abrotanum Linn. and A. pallens Wall. Analytical Chemistry Letters 2(3):186-191.

Temraz A, El-Tantawy WH (2008). Characterization of antioxidant activity of extract from Artemisia vulgaris. Pakistan Journal of Pharmaceutical Science 21(4):321-326.

Toda S (2005). Antioxidative effects of polyphenols from leaves of Artemisia princeps PAMP on lipid peroxidation in vitro. Journal of Food Biochemistry 29:305-312.

Torrell M, Valles J (2001). Genome size in 21 Artemisia L. species (Asteraceae, Anthemideae): Systematic, evolutionary, and ecological implications. Genome 44:231-238.

Valant-Vetschera KM, Fischer R, Wollenweber E (2003). Exudate flavonoids in species of Artemisia (Asteraceae-Anthemideae): new results and chemosystematic interpretation. Biochemical Systematics and Ecology 31:487-498.

Vallés J, Torrell M, Garnatje T, Garcia-Jacas N, Vilatersana R, Susanna A (2003). The genus Artemisia and its allies: phylogeny of subtribe Artemisiinae (Asteraceae, Anthemideae) based on nucleotide sequences of nuclear ribosomal DNA internal transcribed spacers (ITS). Plant Biology 5:274-284.

Vivancos M, Moreno JJ (2005). Beta-sitosterol modulates antioxidant enzyme response in RAW 264.7 macrophages. Free Radical Biological Medicine 39:91-97.

Wojdylo A, Oszmianski J, Czemery R (2007). Antioxidant activity and phenolic compounds in 32 selected herbs. Food Chemistry 105:940949.

Zu Y, Li C, Fu Y, Zhao C (2006). Simultaneous determination of catechin, rutin, quercetin kaempferol and isorhamnetin in the extract of sea buckthorn (Hippophae rhamnoides L.) leaves by RP-HPLC with DAD. Journal of Pharmaceutical and Biomedical Analysis 241:714719. 